\title{
Westerse teks, Alexandrynse teks en die oorspronklike teks van die Nuwe Testament: \\ Is daar'n oplossing vir die probleem?
}

\author{
J H Petzer \\ Universiteit van Suid-Afrika
}

\begin{abstract}
Western text, Alexandrian text and the original text of the New Testament - is there a solution to the problem?
\end{abstract}

This article discusses the debate concerning the problems of the so-called Western text in New Testament textual criticism. Traditional views, such as those of Westcott \& Hort, Ropes, Metzger, Blass, Clark, and Boismard \& Lamouille, all work with the notion of early local text-types. Because of this none of these approaches seems able to solve the problem. In contrast, a fresh approach to the history of the text in general and this problem in particular is developing in Münster. This approach describes the earliest history of the text in terms of 'qualitative' text-types and might therefore have the potential to solve the riddle of the Western text.

In een van sy bekende oorsigte oor die stand van die navorsing ten opsigte van die Westerse teks het die bekende Nederlandse tekskritikus, A F J Klijn, die Westerse teks as die belangrikste enkele probleem in die Nuwe-Testamentiese tekskritiek bestempel en dit duidelik gemaak dat die Westerse teks die sleutel is vir die verstaan van die geskiedenis van die teks van die Nuwe Testament in die algemeen (Klijn 1949:1). Dat hierdie stelling die probleem nie te hoog aanslaan nie en selfs veertig jaar later nog korrek is, is duidelik uit die feit dat die probleme rondom die Wester-

- Lesing gelewer op 27 Mei 1991 tydens 'n nagraadse seminaar by Rhodes Universiteit. 
se teks, veral soos dit in Handelinge na vore tree, in die sentrum van die huidige debat oor die vroegste geskiedenis van die die Nuwe Testament is (vgl bv Petersen 1989, veral 155-156). Dit is duidelik dat wie ook al daarop aanspraak wil maak dat hy die vroegste geskiedenis van die Nuwe Testament verstaan en kan rekonstrueer, in staat sal moet wees om die ontstaan van die Westerse teks bevredigend te verklaar.

\section{WESTCOTT \& HORT}

Hoewel die probleem van die Westerse teks reeds in die werk van agtiende- en negentiende-eeuse tekskritici sigbaar was, was dit latent en kom dit eers in die werk van Westcott \& Hort laat in die negentiende eeu werklik na vore.

Die tekshistoriese model van Westcott \& Hort is goed bekend en behoef geen lang uiteensetting nie (vgl Westcott \& Hort 1974:72vv; Petzer 1987:47-89). Dit onderskei drie lokale tekstipes: die Bisantynse (wat Westcott \& Hort die 'Siriese teks' genoem het), Westerse en Alexandrynse, en 'n kwalitatiewe tekstipe, die Neutrale teks, wat in 'n historiese en kwaliteitsvolgorde geplaas word. Die Neutrale teks, wat hoofsaaklik in die kombinasie van die manuskripte $\mathcal{X}$ en $\mathrm{B}$ gevind word, gee die outograaf die getrouste weer. Onder die lokale tekstipes is die Alexandrynse teks, kwalitatief gesien, die naaste aan die neutrale teks, ofskoon die Westerse teks, histories gesien, ouer as die Alexandrynse teks blyk te wees. Die Siriese teks is, beide histories en kwalitatief gesien, laat en swak en het daarom geen aanspraak op verteenwoordiging van die oorspronklike teks nie.

Ontleed 'n mens hierdie teorie, word die probleem van die Westerse teks meteens duidelik (vgl Epp 1976:237-242). Westcott \& Hort se teorie was naamlik tot 'n groot mate daarop gerig om die Bisantynse of Siriese teks se aanspraak op verteenwoordiging van die oorspronklike teks uit te skakel en het dan ook op 'n uitstekende wyse daarin geslaag om dit te vermag. Die sukses van hierdie poging moet in die kwaliteit van die getuienis wat hulle vir die sekondêre aard van die Bisantynse teks aangevoer het, gesoek word. Hulle het naamlik met behulp van 'n unieke wisselwerking tussen inhoudelike en historiese argumente (interne en eksterne getuienis) aangetoon dat die Bisantynse teks 'n sekondêre karakter het. Dit wil sê, hulle kon aantoon dat die teks inhoudelik 'n eklektiese karakter het en dus van 'n verwerking van bestaande tekstipes getuig, terwyl hulle ook kon aantoon dat die teks histories later as die ander gedateer moet word en eers in die derde/vierde eeu ontstaan het. Die twee argumente vul mekaar aan en bou 'n sterk saak teen die betrokke tekstipe se aansprake op outentisiteit. Die teorie het dus uitnemend geslaag ten opsigte van die uitskakeling van die Bisantynse teks se aansprake, hoofsaaklik omdat dit metodologies goed begrond was. 
Dieselfde teorie het egter misluk ten opsigte van die oplossing van die probleem oor die verhouding tussen die Alexandrynse en Westerse tekste en kon die keuse van die Alexandrynse/Neutrale teks bo die Westerse nie metodologies so oortuigend motiveer nie. Die belangrikste rede hiervoor is die feit dat die wisselwerking tussen dokumentêre of historiese en inhoudelike getuienis nie gehandhaaf kon word nie. Trouens, ten opsigte van hierdie deel van die teksgeskiedenis is 'n spanning tussen die twee soorte getuienis sigbaar. Waar die historiese aspekte van die beskikbare bronne op die primaat van die Westerse teks gedui het, kon Westcott \& Hort interne en inhoudelike argumente aanvoer waarom die Alexandrynse/Neutrale teks bo die Westerse verkiesbaar is. Die kern van die probleem kom daarop neer dat dit lyk of die Westerse teks moontlik ouer en beter versprei was as die Alexandrynse teks, terwyl die Alexandrynse teks egter kwalitatief beter blyk te wees en daarom by implikasie ouer moet wees. Die probleem is egter dat daar geen materiële bewyse van hierdie implisiete ouderdom van die Alexandrynse teks bestaan nie, omdat die oudste manuskripte tot Westcott \& Hort se beskikking, $X$ en $B$, vierde-eeuse manuskripte was. So bestaan daar dus in Westcott \& Hort se teorie oor die vroegste teksgeskiedenis 'n spanning tussen historiese en inhoudelike getuienis, wat hulle voorgestelde oplossing vir die probleem problematies gemaak het.

\section{DIE TRADISIONELE BENADERING}

Hierdie oënskynlike spanning tussen historiese en inhoudelike getuienis ten opsigte van die Westerse en Alexandrynse tekste is steeds die rede waarom die probleem selfs vandag nog nie bevredigend opgelos kon word nie. Die kern van die probleem en daarom ook die inhoud van die debat is steeds dieselfde en draai om dieselfde twee sake: (a) Histories: Hoe moet die ontstaan van die een teks verklaar word as die ander outentiek is? en (b) Inhoudelik: Hoe moet die taalkundige, stilistiese en inhoudelike verskynsels in die verskille tussen die twee tekstipes geëvalueer word?

In die debat (vgl Metzger 1971:259-272; vgl ook Schneider 1987 vir goeie oorsigte) word een van drie posisies gewoonlik oor die saak ingeneem: Sommige tekskritici meen dat die Alexandrynse teks outentiek is, ander meen dat die Westerse teks outentiek is, terwyl nog ander meen dat geeneen outentiek is nie, maar dat individuele lesings van beide die Westerse en Alexandrynse tekste outentiek is en dat hierdie lesings deur 'n eklektiese proses uitgesoek moet word. Elk van hierdie posisies konsentreer op een aspek van die getuienis en beklemtoon die een ten koste van die ander. 


\subsection{Die primaat van die Alexandrynse teks}

In navolging van Westcott \& Hort se teorie is die mees algemene mening oor die saak in die twintigste eeu dat die Alexandrynse teks die oorspronklike teks die getrouste verteenwoordig en dat die Westerse teks 'n latere verwerking van die Alexandrynse teks is. Hierdie posisie, veral soos dit deur Metzger gedefinieer is (vgl Metzger 1968, 1971), word steeds vandag redelik algemeen aanvaar.

Die belangrikste ontwikkeling in hierdie standpunt gedurende die twintigste eeu is dat daar dokumentêre getuienis ten gunste van die primaat van die Alexandrynse teks bygekom het sodat dit nie meer nodig geag word om hierdie teks se voorrang op grond van inhoudelike aspekte alleen te motiveer nie. Dit is, byvoorbeeld, sigbaar wanneer vroeère standpunte oor die saak met meer onlangse standpunte vergelyk word. So neem Ropes (1926) die klassieke posisie in ten opsigte van die teks van Handelinge, deur die Alexandrynse teks as die oorspronklike te beskou en die Westerse teks as 'n tweede-eeuse verwerking van die Alexandrynse teks deur 'n onbekende persoon uit Antiochië. Die rede vir hierdie keuse van die Alexandrynse teks as die primêre is egter steeds basies inhoudelik, naamlik dat die Alexandrynse teks 'n beter kwaliteit as die Westerse teks het. Steeds was daar geen materiële getuienis om die Alexandrynse teks vroeerr as die Westerse te dateer nie. Ropes volg en bevestig dus slegs maar Westcott \& Hort se teorie.

Wat alles egter verander het, was die ontdekking van die papiri. Die eerste belangrike ontdekking, die Chester Beatty-papiri, het nie lank na die publikasie van Ropes se teks plaasgevind nie. Minder as dertig jaar later is die tweede nuwe papirusvonds, die Martin Bodmer-papiri, aan die wêreld bekendgestel. Die grootste waarde van hierdie manuskripte was dat dit meer inligting oor die teks uit die tweede en derde eeu daargestel het. Vir die eerste keer kon die teorie van Westcott \& Hort dus aan die hand van eietydse bronne geëvalueer word. Die verwagting was dat dit die teorie sou bevestig. Aanvanklik het dit dan ook geblyk so te wees.

Die Chester Beatty-papiri het, byvoorbeeld, met die uitsondering van die Caesareaanse teks, geen veranderinge aan die model tot gevolg gehad nie en die papiri is bloot binne die model geakkommodeer (Petzer 1987:26-27). Die Bodmer-papiri het in breë trekke dieselfde gevolg gehad, met die uitsondering daarvan dat die belangrikste manuskrip van hierdie groep $\left(\mathrm{P}^{75}\right)$ 'n duidelike Alexandrynse karakter gehad het en dus die primaat van die Alexandrynse teks skyn te bevestig het.

Hierdie hele ontwikkeling het uitgeloop op die rekonstruksie van die geskiedenis van die teks in Bruce Metzger se teorie (Metzger 1968:207-219; 1971:xv-xxiv). In hierdie teorie is die 'los' drade van die ontwikkelinge gedurende die eeu saamgevat en dit kan dus aanvaar word as verteenwoordigend van die resultate van die twintigste-eeuse navorsing oor die teksgeskiedenis. Dit kan ook beskou word as 'n goeie 
verteenwoordiger van die algemene gevoel oor die teksgeskiedenis tot op daardie stadium.

Ontleed 'n mens egter hierdie rekonstruksie, kan 'n mens nie anders as om iets van 'n teleurstelling te ervaar nie aangesien dit duidelik is dat daar min vordering gemaak is, nieteenstaande die ontdekking van die papiri. Metzger se rekonstruksie sluit naamlik nou by Westcott \& Hort se teksgeskiedenis aan. Slegs 'n naamverandering (Proto-Alexandryns vir Neutraal) en die byvoeging van die Caesareaanse teks verskil van die basismodel van Westcott \& Hort. Ondanks erkende verskille tussen veral die papiri en die manuskripte van Westcott \& Hort se model, probeer Metzger steeds al die papiri binne hierdie model inpas, selfs al is sommige ooglopend uiters moeilik daarmee te rym (vgl bv die 'gemengde' papiri in Metzger 1968: 247-255). Die model het egter 'n redelike algemene aanvaarding in veral die VSA gevind en, met die uitsondering van enkele woestynstemme soos dié van Kurt Aland (1956/1957:264; 1967:89-92; 1970/1971), domineer hierdie model vir jare daarna die toneel, in 'n groot mate selfs vandag nog (vgl bv Ehrman 1986; Fee 1974; Hurtado 1981).

Waarskynlik die belangrikste ontwikkeling in hierdie model is dat daar nuwe dokumentêre feite bygekom het waardeur die primaat van die Alexandrynse teks beter gemotiveer kon word. Dit is naamlik die papiri. Veral $\mathrm{P}^{75}$ wat baie met Kodekse $X$ en veral B ooreenstem (Fee 1974; Porter 1962, 1967), het die materiële getuienis vir die ouderdom van hierdie tekstipe wat Westcott \& Hort ontbeer het, gebied. As sodanig het dit die interne getuienis ten gunste van die primaat van die Alexandrynse teks dus bevestig. Steeds het die interne getuienis egter die belangrike rol gespeel, omdat die getuienis van $\mathbf{P}^{75}$ nie die Alexandrynse teks duidelik tot 'voor' die Westerse teks kon neem nie, maar dit hoogstens gelyk daaraan gestel het. Die algemene gevoel was dat die Alexandrynse teks ouer as die Westerse teks was, maar dat die Westerse teks gedurende die tweede eeu 'n baie groter verspreiding geniet het. Ten opsigte van die Westerse teks is daar min verandering met die basismoderte bespeur. Een van die belangrikste ooreenkomste met die basismodel is dat, hoewel dit die nuutste ontdekkings soos die Westerse papiri en minuskels insluit, dit Kodeks D steeds as een van die vernaamste verteenwoordigers van die Westerse tekstipe beskou.

Soos gesê, is Metzger se model algemeen aanvaar en deur onafhanklike studies ondersteun. So het Eldon Epp, byvoorbeeld, die primaat van die Alexandrynse teks bevestig deur Kodeks Beza inhoudelik te bestudeer en spesifieke inhoudelike tendense daarin te identifiseer (Epp 1966). Uitgaande van die standpunt dat die Westerse teks 'n verwerking van die meer oorspronklike Alexandrynse teks van Handelinge is, het hy die verskille tussen die twee tekste in detail ondersoek. Sy vernaam- 
ste bevinding was dat die (Westerse) teks in Kodeks Beza anti-Judaïstiese kenmerke vertoon (waarin moontlik die oorsaak vir die hersiening van die oorspronklike teks en die gevolglike skepping van die Westerse teks gevind kan word). Hierdie studie het dus gedien om die inhoudelike gronde waarop die Alexandrynse teks bo die Westerse verkies kan word, te versterk. Ook vanuit ander oorde is die sekondêre karakter van die Westerse teks, veral soos dit in Kodeks Beza na vore kom, ondersoek en bevestig. So het Walter Thiele (1965) reeds in die middel van die sestigerjare hierdie manuskrip as die uiteindelike resultaat van 'n ontwikkeling gesien - 'n konklusie wat onlangs in 'n uiters gedetailleerde studie van Kodeks Beza deur David Parker (1990:343-345) bevestig is. Hierdie soort studies dra dus daartoe by om die primaat van die Alexandrynse teks bo die Westerse teks op die een of ander wyse te beklemtoon.

Die ontwikkeling in die kwaliteit van die argumente ten gunste van die primaat van die Alexandrynse teks gedurende die twintigste eeu is duidelik. Waar Westcott \& Hort dit slegs op grond van die inhoudelike eienskappe van die tekstipes kon doen, het die papiri die materiële getuienis wat Westcott \& Hort ontbeer het, gebied. As sodanig is die model dus versterk, met die gevolg dat ander inhoudelike argumente met groter vertroue daargestel kon word. Op hierdie wyse is gepoog om die wisselwerking tussen historiese en inhoudelike argumente wat in Westcott \& Hort ten opsigte van hierdie twee tekstipes ontbreek het, daar te stel.

\subsection{Die primaat van die Westerse teks}

Onder die verdedigers van die primaat van die Westerse teks staan veral drie studies in die twintigste eeu uit, naamlik dié van Blass, Clark en die twee Franse tekskritici, Boismard \& Lamouille. Al drie hierdie ondersoeke het oor Handelinge gehandel.

Blass (1895) se nou reeds bekende teorie beweer dat die skrywer van Handelinge self twee edisies van die Handelingeteks gemaak het. Die eerste was vir die gemeente in Rome bedoel en het die weergawe bevat wat in die Westerse teks gevind word. Die heruitgawe was vir Teofilus bedoel en vir hierdie doel het Lukas die oorspronklike teks veral stilisties hersien. So het die Alexandrynse teks sy beslag gekry. Dit is duidelik dat die basis van hierdie teorie in veral twee inhoudelike eienskappe van die Westerse teks lê, naamlik (a) die feit dat daar ooreenkomste in taal en styl tussen die Westerse teks en die Alexandrynse teks is en (b) die feit dat die aard van die verskille tussen die twee tekste redaksionele of resensionele arbeid suggereer. Die een is naamlik 'n verwerking van die ander en nie bloot net 'n toevallige geïnterpoleerde of verkorte weergawe van die ander nie. 
Clark (1970) benader die probleem effens anders. Hy beweer dat die sleutel tot die oplossing van die probleem geleë is in die feit dat Kodeks Beza in kola en nie in aaneenlopende lyne nie, gekopieer is. Hy beweer dan dat hierdie vorm van die manuskrip nie sy ontstaan by Kodeks Beza gehad het nie, maar by 'n vroeëre argetipe, wat as die argetipe van beide Kodeks Beza en die Alexandrynse teks gedien het. In aansluiting by sy vroeëre tese dat die lang teks meer aanspraak op outentisiteit as die kort teks het (Clark 1918), verklaar hy dan die ontstaan van die korter Alexandrynse teks van Handelinge in terme van die weglating van hierdie kola. Hy beweer naamlik dat wanneer die Alexandrynse teks met Kodeks Beza vergelyk word, dit duidelik word dat die Alexandrynse teks dikwels kort frases, soortgelyk aan die kola in Kodeks Beza, weglaat. Die gevolg van hierdie teorie is dat hy sy weergawe van die oorspronklike teks van Handelinge hoofsaaklik op Kodeks Beza baseer.

Die mees onlangse bydrae tot die debat vanuit hierdie kring is die publikasie van die Handelingeteks deur Boismard \& Lamouille (1984). Die basiese uitgangspunte waarop hierdie teks gebaseer is, is in 1981 deur Boismard in 'n artikel in die gedenkbundel vir Metzger uiteengesit (Boismard 1981; Boismard \& Lamouille 1987). Daarin laat hy die Blass-hipotese herleef (sonder om eksplisiet daarby aan te sluit) deur die probleem van die verhouding van die Alexandrynse en Westerse tekste van Handelinge 'n literêr-kritiese eerder as tekskritiese probleem te maak. Soos Blass, sien Boismard \& Lamouille cok die langer Westerse teks as die oorspronklike, met die Alexandrynse teks die resultaat van 'n verkorting deur die skrywer van Handelinge self. Anders as Blass beskou hulle egter nie die Alexandrynse vorm van die kort teks as Lukas se werk nie, maar beskou hulle dit as die gevolg van 'n tweede resensie en daarom 'n degradering van die oorspronklike verkorting deur die skrywer, Lukas. Die belangrikste motivering vir hierdie hipotese is in bepaalde eienskappe van die taal en styl van die Westerse teks geleë. Hulle beweer naamlik dat die Westerse teks tipies-Lukaanse taal en styl verteenwoordig, terwyl die Alexandrynse teks dit soms doen, maar soms ook weer daarvan afwyk (vgl ook MacKenzie 1985). Dit is op hierdie verskille in die styl van die Alexandrynse en Westerse tekste, dat hulle die betrokkenheid van 'n tweede redaktor begrond. Steeds beskou hulle Kodeks $\mathrm{D}$ as die belangrikste verteenwoordiger van die Westerse teks, maar maak tog in hulle rekonstruksie van die teks dikwels op eklektiese wyse van ander Westerse getuienis gebruik.

Die voorstanders van die primaat van die Westerse teks se argumente vir hulle standpunt is duidelik op inhoudelike of interne aspekte gebaseer. Dit konsentreer veral op die ooreenkomste in taal en styl tussen die Alexandrynse teks van Handelinge en die sogenaamde Westerse veranderings. Opmerklik van hierdie gedagterig- 
ting is die feit dat al drie verteenwoordigers ' $n$ belangrike plek aan Kodeks Beza as verteenwoordiger van die Westerse teks toeken.

\subsection{Nog die Alexandrynse nòg die Westerse teks}

'n Derde rigting onder diegene wat hulle uitspreek oor die verhouding van die twee tekstipes, beweer dat nie een van die twee altyd (of selfs die meeste van die tyd) korrek is nie, maar dat van geval tot geval besluit moet word watter tekstipe die oorspronklike lesing bevat. Gebaseer op George Kilpatrick se siening ten opsigte van die geskiedenis van die teks (Elliott 1990:63-72, 80-97), verkies ook Keith Elliott so 'n eklektiese proses (Elliott 1968:1-11; 1978). Die basiese uitgangspunt daarvan kom in hoofsaak daarop neer dat dit wat van die teksgeskiedenis geweet kan word, geen rol behoort te speel in die besluite ten opsigte van die oorspronklike lesing nie, aangesien nie genoeg van die geskiedenis voor die derde eeu bekend is nie. Omdat alle noemenswaardige doelbewuste arbeid aan die teks teen die einde van die tweede eeu afgesluit is en die beskikbare manuskripte eers daarna gedateer kan word, is die kanse goed dat die tekstipes elk op resensies kan teruggaan wat laat in die tweede eeu plaasgevind het. Die tekstipes verteenwoordig dus latere pogings om uit die corpus lesings tekste te standaardiseer, met die gevolg dat elke tekstipe en elke manuskrip sommige van die oorspronklike lesings bevat. Hierdie resensionele aard van die tekstipes bring mee dat geen tekstipe die oorspronklike teks kan verteenwoordig nie. Gevolglik moet die saak vanuit 'n ander perspektief benader word en moet van geval tot geval besluit word watter lesing die korrekte is en watter nie.

\subsection{Samevatting}

Tussen hierdie drie posisies is die debat vir die grootste deel van die twintigste eeu gevoer en dit is duidelik dat daar 'n skaakmatposisie bereik is. Vir elke argument wat vir die primaat van enige van die tekstipes aangevoer kan word, kan 'n opponerende argument vir die teendeel aangevoer word.

Teen die standpunt dat die papiri die ontbrekende vroeë dokumentêre getuienis ten gunste van die primaat van die Alexandrynse teks verskaf, kan byvoorbeeld daarop gewys word dat die vroeë geografiese verspreiding van die Westerse teks hierdie getuienis ten gunste van die Alexandrynse teks kwalitatief relativeer. Ook kan daarteen aangevoer word dat die papiri nie binne hierdie model inpas nie en dat dit duidelik uit Metzger (1968:247-255) se klassifikasie daarvan blyk. Op dieselfde wyse kan teen Epp se standpunt oor die anti-Judaïstiese tendense in die Westerse teks (Kodeks Beza) gesê word dat dit in werklikheid niks bewys nie, omdat Handelinge self ( = die Alexandrynse teks) reeds sulke tendense bevat. Dit maak enersyds die Westerse teks dus meer Lukaans as Lukas self en andersyds 'n sekon- 
dêre ontstaan daarvoor onmoontlik (vgl Barrett 1979). Verder kan teen die standpunt dat Kodeks Beza die kulminasie van 'n proses is, gestel word dat die taal en styl van die Westerse teks tipies Lukaans is, en dat die tekstipe dus nie uit 'n proses waaraan verskillende mense deelgeneem het, kon ontstaan het nie (vgl Boismard 1981; MacKenzie 1985).

- Aan die ander kant kan dieselfde tipe besware teen die argumente ten gunste van die primaat van die Westerse teks ingebring word. Teen Blass se argument dat Lukas twee uitgawes voorberei het en dat die Alexandrynse teks 'n verkorte weergawe van die oorspronklike uitgawe is, getuig die aard en diversiteit van die bronne van die Westerse teks. Hoe vroeër hulle gedateer word, hoe minder homogeen blyk hulle te wees (vgl Aland 1986). Kenyon (1938) het die laaste woord oor Clark se kola-beskouing gespreek deur op die totale gebrek aan ondersteunende materiële getuienis ten gunste van hierdie teorie te wys. Teen Boismard \& Lamouille se teorie kan gewys word op die probleem om tipiese stilistiese elemente te identifiseer en die verdere probleem om dit as norm vir tekskritiese outentisiteit te gebruik (Geer 1990; Hull 1988; Petzer 1990).

Teen die derde teorie, dié van Kilpatrick en Elliott, getuig die feit dat dit moontlik is om iets van die geskiedenis van die teks reeds vroeg in die tweede eeu te rekonstrueer. Hierdie rekonstruksies dui tog op identifiseerbare patrone in die oorlewering van die teks wat bruikbaar is in die identifisering van die vorm van die oorspronklike teks.

Uit dit wat tot sover bespreek is, is duidelik dat daar ' $n$ hele paar probleme in sowel die debat as in die feite is wat die saak kompliseer en 'n oplossing moeilik, indien nie onmoontlik nie, maak.

Die eerste hou verband met die bronne van die Westerse teks. Vir 'n lang tyd en in 'n sekere sin selfs vandag nog - het Kodeks Beza as die belangrikste bron van die Westerse teks gefunksioneer. Dit het sover gegaan dat hierdie manuskrip op 'n stadium as gelyk aan die Westerse teks beskou is. Die rede daarvoor is nie moeilik om te vind nie. Vir 'n lang tyd was Kodeks Beza die enigste Griekse manuskrip wat tot hierdie teksfamilie behoort het. Kodeks Beza is egter 'n vyfde-eeuse (of hoogstens vierde-eeuse) manuskrip (vgl Parker 1990:39f; 336-337) en die enigste ander getuienis van die bestaan van hierdie teks wat toegelaat het dat dit vroeg gedateer kon word, was sommige van die Latynse, Siriese en Koptiese vertalings en 'n aantal Latynse kerkvaders. Intussen is 'n aantal Westerse papiri gevind en 'n aantal sogenaamde Westerse minuskels is geïdentifiseer. Dit het die vroeë datering van die teks dus bevestig. Die probleem is egter dat al hierdie getuienis in meer as een opsig fragmentaries is. Die manuskripte oorvleuel nie heeltemal met mekaar nie. Verder word nie alle Westerse lesings in al die Westerse bronne aangetref nie. Die 
tipiese Westerse lesings wat in byvoorbeeld die Latynse vertaling voorkom, word nie in die Siriese gevind nie ensovoorts (vgl Aland 1986:57). Hoe vroeër in die geskiedenis teruggegaan word, hoe ernstiger word die probleem.

Die probleem wat hierbo bespreek is, loop uit op die tweede. Dit is naamlik die posisie van Kodeks Beza as verteenwoordiger van die Westerse teks. As hierdie manuskrip dan nie die belangrikste bron van hierdie teks is nie, wat is dit? Daar is vandag al meer mense wat dit eerder as die eindpunt van hierdie tradisie begin sien. Parker (1990:343-345) wys byvoorbeeld op die resensionele karakter van die betrokke manuskrip en die gebrek aan eenheid in die afwykings van die Alexandrynse teks. Ook Thiele (1965) en Barbara Aland (1986) wys op hierdie eienskap van die manuskrip. Dit lyk dus al meer of Kodeks Beza eerder die einde van 'n lang ontwikkeling verteenwoordig as die beginpunt daarvan - 'n einde waarin 'n klomp los drade saamtrek. Hoe dit ook al sy, oor die presiese posisie van hierdie manuskrip is daar nog geen konsensus nie.

Tot sover gesien, maak dit dus meer sin om die Westerse teks as sekondèr en die Alexandryse teks as primêr te sien. Een probleem bly egter oor. Dit is naamlik die feit dat die Westerse teks, veral in Handelinge, meer Lukaans as Lukas self blyk te wees. Dit is uitgewys ten opsigte van die taalgebruik en styl (Boismard 1981; MacKenzie 1985), sowel as ten opsigte van inhoudelike sake, soos die beswaar teen Epp (1966) se beskouing oor die invloed van anti-Judaïsme op hierdie teks (Barrett 1979). Daar is selfs 'n studie wat die orde omgekeer het. Soos Epp die Westerse teks in Handelinge as resepsie van die Alexandrynse gelees het, het Parsons die Alexandrynse teks in die slothoofstukke van die Lukasevangelie as resepsie van die Westerse teks gelees (Parsons 1986). Die resultaat was verrassend deurdat Parsons 'n Christologiese tendens in die 'Alexandrynse veranderinge' kon identifiseer. Of ' $n$ mens nou met die konklusie saamstem of nie, moet die studie ernstig geneem word, omdat dit daarin geslaag het om 'n tendensteks te identifiseer.

Watter teorie ook al voorgestaan word, dit sal daarin moet slaag om hier jie probleme te verklaar. Nie een van die bogenoemde kon dit vermag nie.

Die kernprobleem van al hierdie pogings om die saak op te los is waarskynlik die een gemeenskaplike element in al die bostaande modelle. Dit is naamlik die feit dat dit die vroegste teksgeskiedenis (tweede- en derde-eeuse geskiedenis) binne die konteks van goedgedefinieerde en goedomlynde identifiseerbare lokale tekstipes sien; anders gestel, die voortgaande pogings om die teksgeskiedenis binne die raamwerk van die Westcott \& Hortmodel te verstaan. So sien hulle 'n vroeë onstaan vir beide die Westerse en die Alexandrynse tekste as lokale tekstipes. Al die modelle hierbo neem beide die Westerse en Alexandrynse tekste as tekstipes terug tot by die vroeë tweede eeu en neem ten minste een daarvan terug tot by die skrywer self. Dit 
verraai 'n voortgaande prinsipiële verbondenheid aan Westcott \& Hort en 'n voortgaande neiging om die vroegste teksgeskiedenis op 'n soort anachronistiese wyse vanuit die perspektief van die latere tekstipes te rekonstrueer. Dit is die grootste enkele probleem van die huidige pogings om die teksgeskiedenis te rekonstrueer en myns insiens die belangrikste rede waarom geeneen van die pogings wat hierbo bespreek is, daarin kon slaag om die probleem bevredigend op te los nie.

\section{DIE MÜNSTERSE ALTERNATIEF}

'n Moontlike alternatief vir die tradisionele beskouings oor die saak is in Münster aan die ontwikkel. Die sogenaamde Münsterse teorie is tans egter nog in die proses van ontwikkeling en geensins afgerond nie. Dit het egter ' $n$ vars benadering tot die teksgeskiedenis en het reeds met verrassende resultate na vore gekom. Hoewel nog nie afgerond nie, het hierdie teorie die potensiaal om nuwe oplossings vir die probleem voor te stel.

Die teorie het sy wortels in Kurt Aland se kritiek teen die voortgaande navolging van Westcott \& Hort se teksgeskiedenis in die twintigste eeu (Aland 1956/ $1957,1967,1970 / 1971)$. Die eerste tekens van 'n alternatief vir die tradisionele model is in twee artikels wat vroeg in die tagtigerjare verskyn het, te vinde (Aland 1981, 1982). Dit is in meer besonderhede in die Alands se handboek, wat in die daaropvolgende jaar verskyn het, uitgewerk (Aland \& Aland 1982:57-82). Die hoogtepunt is egter myns insiens in twee artikels van Barbara Aland te vinde (Aland 1986, 1989). Hoewel die model reeds baie interessante resultate opgelewer het, is dit belangrik om te beklemtoon dat dit nog geen afgeronde model is nie. So onlangs soos 1984 het Kurt Aland in sy afskeidsrede by die Instituut gese dat sy werk op die opbou van die Instituut se bronne gefokus het en dat dit die volgende geslag se plig sal wees om die beskikbare inligting te interpreteer (Aland 1985:61-62). Reeds is daarin geslaag om 'n uiters interessante prentjie in 'n relatiewe kort tydjie op te bou.

Die eerste belangrike aspek van die nuwe model is die perspektief waanuit die geskiedenis benader word. In navolging van Aland se kritiek teen die tradisionele model, naamlik dat die vroeëre manuskripte (papiri) nie uit die oogpunt en perspektief van die latere tekstipes bestudeer moet word nie, is hierdie model gebaseer op 'n nuwe bestudering van die papiri sonder die kategorieë van die bestaande lokale tekstipes in die tradisionele model. Dit wil sê, in plaas daarvan dat probeer is om die papiri en ander vroegste manuskripte binne die bestaande lokale tekstipes (Alexandryns, Westers, Bisantyns) te kategoriseer, is hierdie vroegste manuskripte tabula rasa bestudeer ten einde te bepaal of 'n nuwe benadering nie moontlik nuwe kategorieë na vore sal bring nie. Die resultate was inderdaad dat nuwe kategorieë geïdentifiseer is. Op grond van die kwaliteit van die manuskripte is drie kwalitatiewe 
tekstipes of oorleweringstradisies onder hierdie vroegste manuskripte geïdentifiseer, naamlik 'n sogenaamde vaste tradisie, 'n sogenaamde normale tradisie en 'n sogenaamde vrye tradisie. Die manuskripte wat aan die vaste tradisie behoort, lewer die teks baie noukeurig oor; dié wat aan die normale tradisie behoort, bevat 'n aantal tipiese oorleweringsfoute wat die manuskripte tot in hulle finale stadium van oorlewering gekenmerk het; die vrye tradisie bevat manuskripte wat op meer ernstige resensionele arbeid dui.

Wanneer die tipiese eienskappe van hierdie kategorieë manuskripte bestudeer en met mekaar vergelyk word, word twee interessante aspekte van die vroegste oorlewering van die teks duidelik. Die eerste is dat alle ou manuskripte en papiri, ongeag aan watter kategorie dit behoort, dieselfde basiese tekskwaliteit het: Dit is naamlik die basiese eienskappe van die ou Alexandrynse teks. Dit is veral sigbaar in die manuskripte van die vaste teks, maar kom ook in manuskripte van die ander tekstipes voor. Die tweede eienskap van hierdie vroegste papiri is egter dat hulle nie voldoende aan mekaar verwant is sodat hulle in (lokale) tekstipes, soos in die tradisionele model, ingedeel kan word nie. In elkeen van hierdie manuskripte kom bepaalde eiesoortighede voor wat hulle van alle ander onderskei. Sommige van hierdie eiesoortighede openbaar 'n neiging om die teks duideliker en meer verstaanbaar te maak (veral sigbaar in die nomale tradisie), terwyl in ander weer 'n neiging tot groter ingrype in die teks, byvoorbeeld langer byvoegings en weglatings, sigbaar word (veral sigbaar in die vrye tradisie). Hierdie eienskap van die papiri impliseer 'n losse benadering tot die oorlewering van die teks. Dit bring mee dat die teksgeskiedenis nie in sulke vaste kategorieë beskryf word soos in die lokale tekstipemodel nie.

Die tekstipes wat in die tradisionele model erken word, het almal uit hierdie proses ontstaan; ook die Westerse teks. Wat tradisioneel as die Alexandrynse teks bekend gestaan het, is 'n gevolg van die vaste tradisie. Dit is dus nie korrek om na hierdie groep manuskripte, wat in die tradisionele model as die (Proto-)Alexandrynse tekstipe bekend gestaan het, in terme van 'n lokale tekstipe te kategoriseer nie. Hierdie manuskripte getuig in werklikheid van die oorspronklike teks en verteenwoordig geen tekstipe in die tradisionele sin van die woord nie. Die rede vir hierdie beskouing is geleë in die eienskap van die papiri dat hulle almal basiese 'Alexandrynse' eienskappe vertoon, ongeag hoe ver hulle daarvan afwyk. As sodanig vorm hierdie teks (soos dit in $\mathrm{NA}^{26}$ na vore tree) dus die uitgangspunt vir die bestudering van die ander manuskripte.

Word die ander belangrike manuskripte van die Nuwe Testament met hierdie teks vergelyk, word dit duidelik dat ook die eienskappe van die Westerse teks reeds in die papiri sigbaar is. Soos egter reeds vroeër gesê, is die tipiese Westerse lesings 
egter nie binne 'n geheel daar sigbaar nie, maar word individuele lesings in individuele bronne aangetref. Tot laat in die tweede eeu kan daar nog nie van 'n tekstipe gepraat word wanneer na hierdie lesings verwys word nie, maar is dit bloot individuele lesings wat in verskillende bronne voorkom. Word die bronne bestudeer wat hierdie lesings bevat, is daar egter 'n duidelike groei na eenheid te bespeur. Op grond van bepaalde eienskappe van die Siriese teks, wil dit lyk of daar op 'n bepaalde stadium in die tweede eeu in Sirië 'n poging was om die teks te standaardiseer. Hierdie poging het dit wat tradisioneel as die Westerse teks bekend gestaan het, tot gevolg gehad. Selfs na hierdie aanvanklike Westerse resensie, is daar ontwikkeling binne hierdie tekstipe te bespeur. Hierdie 'binne-Westerse' resensionele ontwikke ling loop uiteindelik uit op die produksie van die teks in Kodeks Beza. As sodanig is die Westerse teks dus in werklikheid nie 'n tekstipe nie, maar 'n tekstuele proses, wat in die teks in Kodeks Beza kulmineer. Binne hierdie konteks is dit daarom beter om van die Westerse tradisie eerder as van die Westerse teks of tekstipe te praat. Verder bring die teorie dat die aanvanklike resensie in Sirië plaasgevind het, mee dat daar ook nie meer met die term Westers na hierdie entiteit verwys kan word nie. Omdat die ontwikkeling in Kodeks Beza kulmineer, word die term D-teks as benaming vir hierdie teks gebruik. Vir die doel van hierdie artikel is die belangrikste konsekwensie van hierdie model dus dat daar geen Westerse (of Alexandrynse) teks in die lokale sin van die woord in die tweede eeu bestaan het nie, maar dat die 'Westerse' teks soos dit bekend is, op 'n latere standaardisering van 'n tekstuele tradisie of proses teruggaan.

'n Laaste interessante eienskap van die model is dat dit 'n nuwe benadering tot die 'oorspronklike' teks, wat 'n integrale deel van die model vorm, verteenwoordig. 'Oorspronklike teks' en 'outograaf' word naamlik van mekaar onderskei, deurdat die konsekwensies van die vloeibaarheid en onstabiliteit van die eerste- en tweedeeeuse redaksie- en oorleweringsgeskiedenis van die teks erken word. 'Oorspronklike teks' word in hierdie model in terme van die vroegste identifiseerbare redaksioneel-afgeronde entiteit gedefinieer en nie in terme van die een of ander 'oorspronklike' outeursteks soos dit tradisioneel gedoen is nie. Hierdie 'oorspronklike teks' word egter steeds as oorspronklik gesien in terme daarvan dat die hele bekende oorleweringsgeskiedenis daaraan verbind kan word. Die teks, of dan die tekstipe of tekskarakter in $\mathrm{NA}^{26}$ word in hierdie sin as die oorspronklike beskou.

Wat kan 'n mens van hierdie model sê en hoe moet 'n mens dit beoordeel? In die eerste plek is dit belangrik om te onthou dat die model op geen wyse as 'n afgeronde en finale produk aangebied word nie en verstellings en veranderings kan sekerlik nog in die toekoms verwag word. Tans blyk die model egter baie potensiaal 
te hê deurdat dit daarin slaag om bepaalde probleme in die karakter van veral die papiri op te los.

Die vernaamste winspunt van die model is die perspektief van waaruit die gesḳiedenis benader word, naamlik dat dit vanuit die perspektief van die vroegste beskikbare manuskripte gekonstrueer is. Dit is vervolgens ook 'n winspunt dat dit nie meer nodig is om hierdie manuskripte in vreemde kategorieë ('gemengde tekste') te kategoriseer nie. Verder erken dit die vloeibaarheid en onstabiliteit van die teks in die vroegste periode van oorlewering (vgl Koester 1989) deurdat daar geen lokale tekstipes in hierdie periode erken word nie. Dit slaag egter ook om die bestaan van identifiseerbare tekstipes later in die geskiedenis te verklaar. Op hierdie wyse word eienskappe van sowel die papiri as die latere manuskripte erken en verklaar. Ten slotte slaag dit vir die eerste keer in die Nuwe-Testamentiese tekskritiek daarin om die probleem van die identiteit van die oorspronklike teks en die gevolge van die literêr-kritiese en redaksionele verwerking van hierdie teks vir die tekskritiek te verdiskonteer. Dit is 'n baie belangrike ontwikkeling wat die aard van hierdie hele dissipline kan verander.

Nieteenstaande die voordele van hierdie model is daar tog veral twee probleme. Die eerste is die gebruik van $\mathrm{NA}^{26}$ as uitgangspunt vir die model en die feit dat alle verskille met hierdie teks as afwykings van die oorspronklike beskou word. Hoewel dit as 'n werkhipotese voorgehou word, moet nog uitgemaak word wat $\mathrm{NA}^{26}$ (of die 'Alexandrynse' element in die vroegste teksgeskiedenis) presies verteenwoordig. Die ooglopende gevaar van 'n sirkelredenasie is hier duidelik.

In die tweede plek is dit nog 'n vraag of hierdie model daarin slaag om die een eienskap van die 'Westerse' teks, naamlik dat dit meer 'Lukaans as Lukas self' blyk te wees (ten minste sover as wat dit Handelinge betref), bevredigend te verklaar. Die feit dat die 'oorspronklike teks' nie as 'n outeursteks beskou word nie, maak die hele probleem natuurlik irrelevant, omdat enige stilistiese patroon in 'n redaksionele teks toevallig is en nie normatief vir outentisiteit kan wees nie. Watter stilistiese patroon daarom in enige teks van Handelinge ontdek word, is uit hierdie oogpunt gesien die gevolg van 'n latere redaktor en nie van die skrywer nie, met die gevolg dat die een soveel werd is as die ander en geeneen as norm vir oorspronklikheid kan dien nie (Petzer 1990).

Dit is dus duidelik dat, hoewel hierdie model daarin slaag om bepaalde probleme uit die weg te ruim, daar steeds probleme oorbly wat nog opgelos moet word. 'n Mens sien met verwagting uit na verdere resultate van die projek by Münster. 


\section{KONKLUSIE}

Nie een van die modelle wat hierbo bespreek is, slaag tans daarin om die probleem van die verhouding tussen die Alexandrynse en Westerse tekste ten volle op te los nie en dit is duidelik dat die laaste woord daaroor nog nie gespreek is nie. Onder die modelle wat bespreek is, slaag die nuwe Münsterse model egter tans daarin om die meeste van die probleme op te klaar, selfs al is die model nog nie ten volle afgerond nie. Die model hou veral een belangrike voordeel bo die tradisionele modelle in: Dit is dat dit ' $n$ meer komplekse visie van die vroegste teksgeskiedenis het. In hierdie visie word ruimte gemaak vir die diversiteit en onstabiliteit van die teks, die groei van die tradisie en die veranderings in die literêre toestand van die teks.

Hierdie kompleksiteit en onstabiliteit van die vroegste geskiedenis is op uitstekende wyse deur onafhanklike ondersoeke bevestig. Baarda (1989) het byvoorbeeld gewys dat die Evangelieharmonieë moontlik binne 'n voortgaande redaksionele tradisie, soortgelyk aan dit wat in die Sinoptiese Evangelies vergestalt word, staan en dat die harmonieë moontlik 'n laaste redaksionele poging binne die geheel van die proses om die tradisie te standaardiseer, verteenwoordig. Koester (1989) het weer gewys hoe onstabiel die teks in die tweede eeu was, deur onder ander na die moontlike invloed van tradisies en lesings in buite-kanonieke boeke op die kanonieke tradisies te wys. Beide hierdie standpunte ondersteun die belangrikste aspek van die Münsterse model, naamlik dat die teks aanvanklik in geen vaste bane oorgelewer is nie en dat die lokale tekstipes 'n latere ontwikkeling is. Aanvaar 'n mens hierdie soort uitgangspunt, is dit duidelik dat die tradisionele benadering met sy vaste lokale tekstipes nie meer geskik is om die geskiedenis akkuraat te rekonstrueer nie en is dit duidelik dat 'n meer dinamiese model daarvoor nodig is. Die Münsterse model het die potensiaal om so 'n benadering te ontwikkel.

\section{Literatuurverwysings}

Aland, B 1986. Entstehung, Character und Herkunft des sog. westlichen Textes untersucht an der Apostelgeschichte. ETL 62, 5-65.

--- 1989. Die Münsteraner Arbeit am Text des Neuen Testaments und ihr Beitrag für die frühe Überlieferung des 2. Jahrhunderts: Eine methodologische Betrachtung, in Petersen 1989:55-70.

Aland, K 1956/1957. Neue neutestamentliche Papyri. NTS 3, 261-286.

.-- 1967. Die Konzequenzen der neueren Handschriftenfunde für die neutestamentliche Textkritik. NT 9,81-106. 
Aland, K 1970/71. Bemerkungen zu den gegenwärtigen Möglichkeiten textkritischer Arbeit aus Anlass einer Untersuchung zum Cäsarea-Text der katholischen Briefe. NTS 17, 1-9.

--. 1981. Der neue 'Standard-Text' in seinem Verhältnis zu den frühen Papyri und Majuskeln, in Epp \& Fee 1981:257-275.

-.- 1982. Der Textcharakter der frühen Papyri und Majuskeln, in Bericht der Hermann Kunst-Stiftung zur Fördenung der Neutestamentlichen Textforschung für die Jahre 1979 bis 1981, 43-68. Münster: Hermann Kunst-Stiftung.

--- 1985. Die Grundurkunde des Glaubens. Ein Bericht über 40 Jahre Arbeit an ihrem Text, in Bericht der Hermann Kunst-Stiftung zur Fördenung der Neutestamentlichen Textforschung für die Jahre 1982 bis 1984, 9-75. Münster: Hermann Kunst-Stiftung.

Aland, K \& Aland, B 1982. Der Text des Neuen Testaments: Einführung in die wissenschafilichen Ausgaben sowie in Theorie und Praxis der modernen Textkritik. Stuttgart: Deutsche Bibelstiftung. (Engelse uitgawe deur Brill, Leiden 1987; tweede Engelse uitgawe in 1989.)

Baarda, Tj 1989. $\triangle I A \Phi \cap N I A-\Sigma \Psi M \oplus \cap N I A$ : Factors in the harmonization of the Gospels, especially in the Diatessaron of Tatian, in Petersen 1989:133-154.

Barrett, C K 1979. Is there a theological tendency in Codex Bezae? in Best \& Wilson 1979:15-27.

Best, E \& Wilson, R (eds) 1979. Text and interpretation: Studies in the New Testament presented to Matthew Black. Cambridge: Cambridge University Press.

Blass, F 1895. Acta Apostolonum sive Lucae ad Theophilum liber Alter. Göttingen: Vandenhoeck.

Boismard, M-E 1981. The text of Acts: A problem of literary criticism? in Epp \& Fee 1981, 147-157.

Boismard, M-E \& Lamouille, A (eds) 1984. Le texte occidental des Actes des Apótres. Parys: Editions Recherche sur les Civilisations.

-.- 1987. Le texte occidental des Actes des Apôtres: A Propos de Actes 27:1-13. ETL 63, 48-58.

Clark, A C 1918. The descent of manuscripts. Oxford: Clarendon.

-- [1933] 1970. The Acts of the Apostles: A critical edition with introduction and notes on selected passages. Oxford: Clarendon.

Daniels, B L \& Suggs, M J (eds) 1967. Studies in the history and text of the New Testament in honor of Kenneth Willis Clark. Salt Lake City: University of Utah Press. (Studies \& Documents 29.)

Ehrman, B D 1986. Didymus the Blind and the text of the Gospels. Georgia: Scholars Press. (The New Testament in the Greek Fathers 1.) 
Elliott, J K 1968. The Greek text of the Epistles to Timothy and Titus. Salt Lake City: University of Utah Press.

-- (ed) 1990. The principles and practice of New Testament Textual Criticism: Collected essays of $G$ D Kilpatrick. Leuven: Peeters. (BETL 96.)

Epp, E J 1966. The theological tendency of Codex Bezae Cantabrigiensis in Acts. Cambridge: Cambridge University Press. (SNTS Monograph Series 3.)

-. 1976. The eclectic method in New Testament textual criticism: Solution or symptom? HTR 69, 211-257.

Epp, E J \& Fee, G D (eds) 1981. New Testament Textual Criticism: Its significance for exegesis. Essays in honour of Bruce M Metzger. Oxford: Clarendon.

Fee, G D 1974. P75, P66 and Origen: The myth of early textual recension in Alexandria, in Longenecker \& Tenney 1974:19-45.

Geer, C G 1990. The presence and significance of Lucanisms in the 'Western' Text of Acts. JSNT 39, 59-76.

Hull, R F 1988. 'Lucanisms' in the Western text of Acts? A reappraisal. JBL 107, 695-707.

Hurtado, L W 1981. Text-critical methodology and the pre-Caesarean text-Codex W in the Gospel of Mark. Grand Rapids: Eerdmans. (Studies and Documents 43.)

Kenyon, F C 1938. The Western Text in the Gospels and Acts, in Proceedings of the British Academy 1938:287-315.

Klijn, A F J 1949. A survey of the researches into the Western text of the Gospels and Acts. Doktorale proefskrif, Rijkuniversiteit: Utrecht.

Koester, H 1989. The text of the Synoptic Gospels in the second century, in Petersen 1989:19-37,

Longenecker, R N \& Tenney, M C (eds) 1974. New dimensions in New Testament study. Grand Rapids: Zondervan.

MacKenzie, R S 1985. The Western text of Acts: Some Lucanisms in selected sermons. $J B L 104,637-650$.

Metzger, B M 1968. The text of the New Testament: Its transmission, comption and restoration. 2nd ed. New York: Oxford University Press.

-- 1971. A textual commentary on the Greek New Testament - A companion volume to the United Bible Societies' Greek New Testament. London: UBS.

Parker, D C 1990. Codex Bezae: An early Christian manuscript and its text. Doktorale proefskrif, Rijksuniversiteit, Utrecht.

Parsons, M C 1986. A christological tendency in $\mathrm{P}^{75}$. JBL 105, 463-479.

Petersen, W (ed.) 1989. Gospel traditions in the second century: Origins, recensions, text, and transmission. Notre Dame: University of Notre Dame Press. 
Petzer, J H 1987. Nuwe-Testamentiese tekskritiek sedert 1881: 'n Kritiese evaluering van die belangrikste metoderigtings, met besondere verwysing na die laaste gedeelte van die twintigste eeu. Doktorale proefskrif, PU vir CHO, Potchefstroom.

-.- 1990. Author's style and the textual criticism of the New Testament. Neotestamentica 24, 185-197.

Porter, C L 1962. Papyrus Bodmer XV $\left(\mathrm{P}^{75}\right)$ and the text of Codex Vaticanus. JBL 81, 363-376.

-- 1967. An analysis of the textual variation between pap75 and the Codex Vaticanus in the text of John, in Daniels \& Suggs 1967:71-80.

Ropes, J H 1926. The text of Acts. London: Macmillan. (The Beginnings of Christianity, Pt 1, vol 3.)

Schneider, G 1987. Zum 'westlichen' Text der Apostelgeschichte. BZ 31,138-144.

Thiele, W 1965. Ausgewählte Beispiele zur charakterisierung des 'westlichen' Textes der Apostelgeschichte. ZNW 56, 51-63.

Westcott, B F \& Hort, F J A [1881], 1974. The New Testament in the original Greek, Pt 2: Introduction and appendix. Graz: Akademische Druck- und Verlagsanstalt. 